\title{
THE EFFECT OF CAREER DEVELOPMENT AND WORK DISCIPLINE TO JOB SATISFACTION OF PROGRAMMING DEPARTMENT EMPLOYEES AT PT. $X$
}

\author{
Anti Purnamasari ${ }^{1}$ \\ ${ }^{1}$ Faculty of Economics, Universitas Negeri Jakarta \\ Jakarta, Indonesia \\ antipurnama31@gmail.com \\ Dr. Agung Wahyu Handaru, ST, M.M. ${ }^{2}$ \\ ${ }^{2}$ Faculty of Economics, Universitas Negeri Jakarta \\ Jakarta, Indonesia \\ agung_1178@yahoo.com \\ Dr. Widya Parimita, S.E., M.P.A ${ }^{3}$ \\ ${ }^{3}$ Faculty of Economics, Universitas Negeri Jakarta \\ Jakarta, Indonesia \\ widya.parimita@gmail.com
}

\begin{abstract}
This study aimed to determine the effect of Career Development and Work Discipline on the work of Programming employees at PT. X. The subject of this research is PT. $\mathrm{X}$, which is one of the private TV stations in Indonesia and located in Jakarta. The population of this study was 116 people, and the sampling method used was saturated sampling, so the number of samples in this study was also 116 people. This research used the multiple linear regression analysis methods in analyzing research data. The results showed that Career Development and Work Discipline had a significant positive effect on work, either separately or simultaneously. This implies that if there is an increase in career development and employees' work discipline, the job satisfaction felt by employees will also increase
\end{abstract}

Keywords: Career Development, Work Discipline, Work Satisfaction, Need Fulfillment Theory 


\section{INTRODUCTION}

Every company wants maximum results from each employee. One way to achieve this is to increase job satisfaction. When employees feel satisfaction at work, they will try their best to produce maximum results in completing their work (Fadhilah, 2010). However, if there are employees who are dissatisfied with their work, this can lead to various problems. This is stated by Singh et al. (2016), where job dissatisfaction experienced by employees can impact high absenteeism and hinder the company's capability in achieving company goals. Employees who are dissatisfied with both the job and the company will also look less enthusiastic, and there will be no encouragement from employees to work optimally. If this is allowed, it can reduce the company's performance and have an impact on the profits generated.

The problem of employee dissatisfaction can be found in the programming section of PT. $X$. PT. $X$ is a national private television station that broadcasts various quality programs and is located in Jakarta. The company's programming department has an important role in scheduling program broadcasts to sort programs that are categorized as eligible for broadcast.

Based on the exposure of the local human resource department, several employees did not come to work and tended not to complete their duties correctly. If left too long, it can reduce the company's performance, resulting in the difficulty of achieving company goals. Employees who feel they do not have job satisfaction can be seen from how they behave towards the company. Attitudes that are easy to find if there is dissatisfaction at work can be seen from how the employee is present. This is supported by Parimita et al. (2017), where employees who feel dissatisfied at work can be seen from the level of absenteeism that impacts the routine work activities of each employee.

The average absenteeism in the company is relatively high, with an average percentage of $3.36 \%$ per month. This can indicate a lack of sense of responsibility that employees have towards the company and has exceeded the tolerance limit given by the company. Based on the explanation from HRD, many employees used the opportunity to take leave exceeding the tolerance limit where there were employees who did not enter more than once, and the rest were employees who did not attend with a permit for personal matters. 
This absence rate is explained by Lusigita (2017). The absenteeism rate that is considered suitable ranges from $2 \%$ to $3 \%$, poor absenteeism in the company is indicated by the absenteeism of $3 \%$ and above.

Researchers try to find out the cause of the high level of employee absenteeism in the company. Based on the data that researchers got from the company, it was found that two main factors were causing the employee's career development to be hampered, coupled with the employee's work discipline that was still not good. Career development is an individual effort in managing their career and steps to develop their career in an organization, but the company also takes part in helping employees to develop their careers and planning a series of agendas to achieve them (Kitana \& Karam, 2017). While Arab et al. (2019) describes work discipline as an activity carried out from employee behavior in complying with written or unwritten regulations. Disciplined employees demonstrate good behavior and comply with company policies.

Concerning career development, in recent years, very few employees have had the opportunity to develop their careers, where less than ten employees have received promotions, rotations, and transfers. The small number of employees who get the opportunity is certainly an unsatisfactory thing, considering that many employees want a transfer to another division or want to get a promotion. The low number of employees who get opportunities for promotion, rotation, and transfer can indicate a lack of transparency from the company regarding their career development policies, which causes employees to not have good guidelines in developing their careers. The theory of Sheraz et al. (2019) explains career development policies in the company, where professional improvement programs in employee career development can have an impact on employee job satisfaction. If the company does not have some kind of career development program or does not run well, it can have an impact on the lack of employee satisfaction and impact on their work.

Then related to work discipline, according to the explanation from HRD, the low discipline that occurs in the company is caused by several things, ranging from some employees who arrive late, employees who do not use self-identity, and lack of neatness of employees, In addition, some employees are also unable to complete work on time. These conditions can certainly hinder the regulations that have been set by the company 
considering that PT. X is a national television company. If left unchecked, this lack of discipline can hinder the company's ability to achieve its goals. The conditions described by HRD follow the theory from Zainal (2017), where the evaluation of discipline can be observed from the timeliness required to attend, completion of tasks, working hours to the achievement of work results.

Regarding the effect of career development on job satisfaction, several studies such as those conducted by Santoso \& Sidik (2020), Parashakti et al. (2019), Sheraz et al. (2019), Parimita et al. (2017), Kitana \& Karam (2017), and Kaya \& Ceylan (2014) which state that career development has a significant influence on job satisfaction. Then regarding the influence of work discipline on job satisfaction, several studies such as those conducted by Santoso \& Sidik (2020), Yadewani \& Wijaya (2019), Sudarsih \& Supriyadi (2019), Arab et al. (2019), and Natsir et al. (2018) shows that work discipline has a significant effect on job satisfaction.

There is a research gap regarding the effect of career development on job satisfaction. several studies, such as those conducted by Santoso \& Sidik (2020) titled "Effect of Career Development, Work Discipline and Work Environment to Job Satisfaction," shows that career development has a significant effect on job satisfaction. Another study conducted by Sheraz et al. (2019) titled "Employee's Retention and Job Satisfaction: Mediating Role of Career Development Programs" also shows that career development has a significant effect on job satisfaction.

Meanwhile, a study conducted by Parashakti et al. (2019) titled "The Effect of Workload, Work Environment, Career Development on Employee Job Satisfaction on PT. Sari Coffee Indonesia, Tbk" shows that career development does not have a significant effect on the employee's job satisfaction. Another study conducted by Kaya \& Ceylan (2014) titled "An Empirical Study on the Role of Career Development Programs in Organizations and Organizational Commitment on Job Satisfaction of Employees" also shows that career development does not have a significant effect on the employee's job satisfaction.

There is also exists a research gap regarding the influence of work discipline on job satisfaction. Several studies, such as those conducted by Santoso \& Sidik (2020) titled "Effect of Career Development, Work Discipline and Work Environment to Job 
Satisfaction," show that work discipline has a significant effect on job satisfaction. Another study conducted by Yadewani \& Wijaya (2019) titled "The Relationship between Reward, Work Discipline, Motivation, and Employee Job Satisfaction among Employees of Inews Tv Padang, Indonesia also shows that work discipline has a significant effect on job satisfaction.

Meanwhile, a study conducted by Wuysang \& Tawas (2016) titled "The Influence of Work Discipline, Leadership Behavior and the Work Motivation on Job Satisfaction and Job Performance of Employee In KFC Bahu Mall Manado" shows that work discipline does not have a significant effect on job satisfaction. Another study conducted by Qarismail \& Prayekti (2020) titled "The Effect of Transformational Leadership Style, Motivation and Work Discipline on Employee Job Satisfaction: Study at The Westlake Resort Yogyakarta" also shows that work discipline does not have a significant effect on job satisfaction.

This background underlies the researcher's reasons to make this problem the basis of this research. Therefore, the purpose of this research is to find out the description of career development, work discipline, and job satisfaction in the company, and to see whether career development and work discipline have a significant influence on job satisfaction, either separately or simultaneously.

\section{LITERATURE REVIEW}

\section{Job Satisfaction}

Job satisfaction has different interpretations, according to the experts who say it. According to Mrhálek \& Kajanová (2017), job satisfaction can be interpreted as behavior towards work, both positive and negative emotional states that come from work life. Job satisfaction can arise from how employees evaluate employees' work every day that can bring up certain feelings.

The opinion of job satisfaction by Tepret \& Tuna (2015) is a feeling of happiness obtained when doing work. Job satisfaction can cover a broad surface in the sense that there is a positive reaction from employees regarding their work conditions and creates feelings of pleasure when doing the job. In comparison, Aluf et al. (2017) describe job satisfaction as an emotional condition obtained from the evaluation of work experience that has the 
potential to satisfy individuals. Employees who tend to like their work will show their liking for the work they have.

From these various explanations, it can be synthesized that job satisfaction is an individual's emotional attitude that appears in the form of feelings of happiness and creates certain feelings both in positive and negative terms based on the evaluation of individual work experience on work life.

Regarding job satisfaction in this study, researchers used Need Fulfillment Theory, where job satisfaction problems occurred at PT. X relates to meeting the needs of employees for their work. If employees feel their needs are being met, then employees will feel satisfied, but if not, there will be dissatisfaction (Ilahi et al., 2017).

\section{Career Development}

Many experts argue related to career development. Kitana \& Karam (2017) describe career development as an individual effort to manage their career and develop their career in an organization. The company also takes part in helping employees to develop their careers and planning a series of agendas to achieve them. Sholikhah et al. (2018) define career development as a set of individual behavior transitions in finding valuable skills and abilities to develop themselves and their careers over a certain period. Attitude changes made by individuals are also adjusted to their needs in career development and evaluated to be applied in achieving the desired career goals. From these various definitions, it can be concluded that career development is a series of behavioral transitions and individual efforts to manage their careers in companies by following different complex organizational mechanisms, both education, and training, in developing their skills over a certain period.

Regarding career development in this study, researchers used The Theory of Work Adjustment because of career development problems at PT. X relates to obstacles that arise in the career development process, both from the employees themselves and the company. This theory is based on individual differences and vocational behavior, where career choice is seen as an unbroken process consisting of adjustment and accommodation (Jena \& Nayak, 2020)

Based on the description above, it can be hypothesized that career development has a significant positive effect on job satisfaction. This influence is explained by Manonmani 
(2019) which states that success in careers achieved by employees will have a positive impact on the personal life of the employee because employees have the opportunity to meet their needs and improve their standard of living, therefore with a budding career, employees will feel satisfied with his job. Rahman et al. (2016) also stated the same thing, which explained that good career development would increase the benefits received by employees from their company, ranging from salaries, benefits, and the prestige of their work, so that employees will feel satisfied with their job because of the benefits they receive from their work. Will improve the welfare of the employee. In addition, Kaya $\&$ Ceylan (2014) explain that current employees are not only looking for financial satisfaction but also moral satisfaction. Each employee will have career ambitions that they hope they will derive from their work. Therefore, if employees can develop their careers, employee satisfaction will also increase.

\section{Work Discipline}

There are several definitions related to work discipline. According to Yadewani \& Wijaya (2019), discipline is individual awareness of complying with applicable rules or norms. This behavior can be shown from the attitudes and responsibilities of employees who are subject to all forms of policies implemented by the company. While Arab et al. (2019) describes work discipline as an activity carried out from employee behavior complying with written or unwritten regulations. Disciplined employees demonstrate good behavior and comply with company policies. From these various definitions, it can be concluded that work discipline is an individual's awareness and understanding in complying with all regulations, both written and unwritten, and subject to company policies.

Regarding work discipline in this study, researchers used Positive Discipline Theory because of work discipline problems at PT. X relates to the non-fulfillment of the discipline targets set by the company, so a joint solution is needed between employees and the company to avoid work discipline problems in the future. This theory is based on the assumption that employees should be held accountable for their actions, and they should have a desire to improve their behavior. When a problem arises, the employee is not punished immediately, but the employee and the company look for ways to avoid the situation in the future. (Bugdol, 2018). 
Based on the description above, it can be hypothesized that work discipline has a significant positive effect on job satisfaction. This influence is explained by Sudarsih \& Supriyadi (2019), which state that company regulations are formed to direct employees to complete the tasks and work assigned to them properly following the standards set by the company. So that when they can behave in a disciplined manner, their work can be completed properly so that employees can feel satisfied with the results of their work. Another opinion from Harinoto (2017) explains that self-discipline from employees can train, improve, and shape the knowledge, attitudes, and behavior of the employees themselves so that when employees carry out their work, they can do their jobs optimally so that employees will feel more satisfied than before. Then Ifriana \& Susanti (2019) stated, the existence of work discipline will increase employee enthusiasm and high work enthusiasm and will encourage employees to work more productively so that in turn will be able to increase employee work productivity. Those who have high spirits, obey the rules set by the institution, are creative, and can use the facilities properly will be able to compete in today's increasingly competitive conditions.

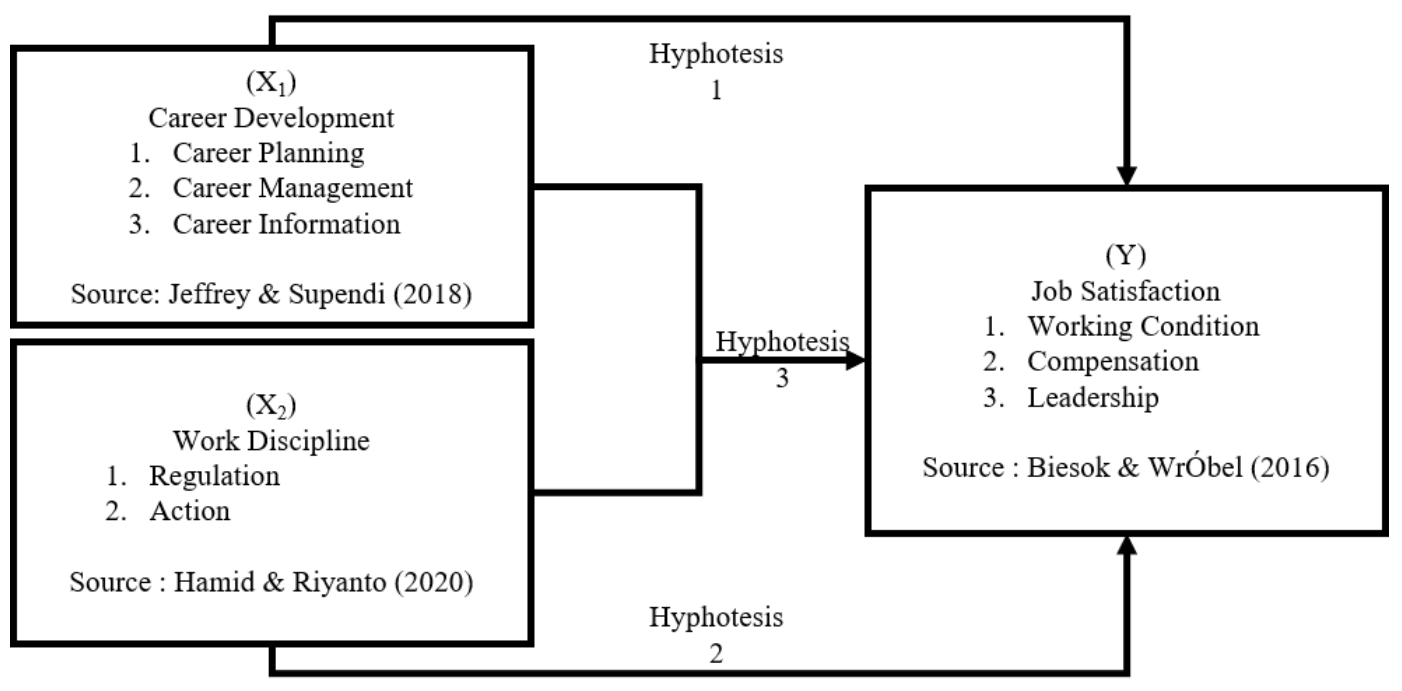

Figure 1. Research Model

Source : Data proccesed by author (2021)

\section{Research Hyphotesis}

For the first hypothesis, the Hol is "Career development does not affect the job satisfaction of employees in the programming department at PT. X." Meanwhile, the Ha1 
is "Career development affects the job satisfaction of employees in the programming department at PT. X”

For the second hypothesis, the Ho2 is "Work discipline does not affect the job satisfaction of employees in the programming department at PT. X." Meanwhile, the Ha2 is "Work discipline affects the job satisfaction of employees in the programming department at PT. X."

For the third hypothesis, the Ho3 is "The research model of career development and work discipline cannot predict the job satisfaction of employees in the programming department at PT. X." Meanwhile, the Ha3 is "The research model of career development and work discipline can predict the job satisfaction of employees in the programming department at PT. X”

\section{RESEARCH METHOD}

Researchers decided to research PT. X, one of the private tv stations in Indonesia, is engaged in television broadcasting services. The research began in March 2020 by conducting periodic interviews with the company to find out an overview of the problems that occur in the company related to organizational commitment, work involvement, and job satisfaction. Furthermore, this research runs until March 2021. The population of this study consists of 116 staff from the programming division of PT. X, and for sample selection, the researcher used the saturated sampling method, which determines the sample when all members of the population are used as samples. Therefore, the sample of this research is all the programming staff of PT. X as many as 116 people.

This study uses quantitative methods, namely research that uses data analysis by describing the data numerically or through numbers. The purpose of quantitative research itself is to develop, test, and use mathematical models, theories, and hypotheses related to the phenomenon or problem being investigated. The research design used a descriptive and causal research approach. Descriptive research is defined as research that describes a characteristic of the variables studied. Meanwhile, causal research aims to identify causeand-effect relationships between variables and understand the functions of independent and dependent variables. 


\section{Statistic Descriptive}

The assessment of the Likert scale used in this study uses five answer categories adapted from Sekaran \& Bougie (2016) to check how strong the subject agrees or disagrees with the statement given.

Table 1. Scale of Research Measurement

\begin{tabular}{ccc} 
Score & Answers Category & $\begin{array}{c}\text { Answers Category } \\
\text { (Negative Indicators) }\end{array}$ \\
\hline 1 & Strongly Disagree (STS) & Strongly Agree (SS) \\
2 & Disagree (TS) & Agree (S) \\
3 & Neutral (N) & Neutral (N) \\
4 & Agree (S) & Disagree (TS) \\
5 & Strongly Agree (SS) & Strongly Disagree (STS) \\
\hline \multicolumn{3}{c}{ Source : Data proccesed by author (2021) }
\end{tabular}

To make it easier for researchers in interpreting the results research obtained from the questionnaire of each variable, the researcher refers to the following table of the interpretation criteria:

Table 2. Statistic Descriptive Interpretation Criteria

\begin{tabular}{cccc} 
Kriteria Skor & $\begin{array}{c}\text { Career Development } \\
\text { (STS + TS) }\end{array}$ & $\begin{array}{c}\text { Work Discipline } \\
\text { (STS + TS) }\end{array}$ & $\begin{array}{c}\text { Job Satisfaction } \\
\text { (STS + TS) }\end{array}$ \\
\hline $0-20 \%$ & Very High & Very High & Very High \\
$21-40 \%$ & High & High & High \\
$41-60 \%$ & Neutral & Neutral & Neutral \\
$61-80 \%$ & Low & Low & Low \\
$81-100 \%$ & Very Low & Very Low & Very Low \\
\hline
\end{tabular}

Source : Data proccesed by author (2021)

\section{Multiple Linear Regression}

Multiple linear regression analysis is a linear regression that connects the dependent variable to two or more independent variables in a study. The application of this method is to predict or predict the value of the dependent variable which is influenced by the independent variable (Ghozali, 2018). Multiple linear regression equations can be calculated using the following equation:

$$
\mathrm{Y}=\alpha+\beta_{1} \mathrm{X}_{1}+\beta_{2} \mathrm{X}_{2}
$$


Description:

$$
\begin{aligned}
& \mathrm{Y}=\text { dependent variable in research } \\
& \alpha \quad=\text { constant (intercept) value } \\
& \beta_{1}, \beta_{2}=\text { coefficient regression value of independent variable } \\
& \mathrm{X}_{1}, \mathrm{X}_{2}=\text { independent variable }
\end{aligned}
$$

\section{RESULTS AND DISCUSSION}

Descriptive analysis aims to determine the general description of the company's condition related to the research variables. For career development variables, the first dimension (Career Planning) has a total STS + TS percentage of $81.90 \%$, which indicates that this dimension is in the very low category. This is because $83.6 \%$ of employees do not have work experience that can help them develop their careers. Then the second dimension (Career Management) has a total STS + TS percentage of $81.00 \%$, which indicates that this dimension is in the very low category. This is because $87 \%$ of employees think that the company does not have a rotation program to help employees find their passion for work. Then the third dimension (Career Information) has a total STS + TS percentage of $85.60 \%$, which indicates that this dimension is in the very low category. This is because $91.30 \%$ of employees consider that the company does not openly disseminate information related to career development. From the overall average of career development variables, it can be seen that the total percentage of STS + TS is $82.74 \%$. When compared with the weight of the score interpretation criteria, the career development variable is in the Very Low category. This indicates that the work involvement of the employees of the programming division of PT. $\mathrm{X}$ is still very low.

For the work discipline variable, the first dimension (Regulation) has a total percentage of STS + TS of $82.77 \%$, which indicates that this dimension is in the very low category. This is because $93.1 \%$ of employees consider that the applicable regulations in the company are still unclear and have multiple interpretations. Then the second dimension (Actions) has a total percentage of STS+TS of $87.07 \%$, which indicates that this dimension is in the very low category. This is because $89.6 \%$ of employees feel that the preventive policies implemented by the company are still not good in improving discipline in the company. From the overall average of work discipline variables, it can 
be seen that the total percentage of STS + TS is $84.92 \%$. When compared with the weight of the score interpretation criteria, the work discipline variable is in the Very Low category. This indicates that the work involvement of the employees of the programming division of PT. $\mathrm{X}$ is still very low.

For the job satisfaction variable, the first dimension (Work Conditions) has a total STS + TS percentage of $80.13 \%$, which indicates that this dimension is in a low category. This is because $84.4 \%$ of employees feel that safety and comfort at work have not supported them in doing their job. Then the second dimension (Compensation) has a total percentage of STS+TS of $77.60 \%$, which indicates that this dimension is in a low category. This is because $80.2 \%$ of employees do not get additional incentives from the company. Then the third dimension (Leadership) has a total STS + TS percentage of $78.10 \%$, which indicates that this dimension is in a low category. This is because $79.3 \%$ of employees are not treated fairly by their superiors. From the overall average of job satisfaction variables, it can be seen that the total percentage of STS + TS is $78.61 \%$. When compared with the weight of the score interpretation criteria, the job satisfaction variable is in the Low category. This indicates that the job satisfaction of the employees of the programming division of PT. $\mathrm{X}$ is still very low..

\section{Table 3. Validity Test Results}

\begin{tabular}{ccc} 
Variables & $\begin{array}{c}\text { Statement } \\
\text { Item }\end{array}$ & $\begin{array}{c}\text { Valid Statement } \\
\text { Item }\end{array}$ \\
\hline $\begin{array}{c}\text { Career Development } \\
\left(\mathrm{X}_{1}\right)\end{array}$ & 10 & 10 \\
Work Discipline & 6 & 6 \\
$\left(\mathrm{X}_{2}\right)$ & 9 & 9 \\
Job Satisfaction \\
$(\mathrm{Y})$
\end{tabular}

A validity test is used to test whether the questionnaire data is valid or not. The validity test in this research uses the Corrected Item Total Correlation method with a significant level of $5 \%$. How to measure validity is that if $r$ count $>r$ table, then the item can be declared valid; if $\mathrm{r}$ count $<\mathrm{r}$ table, the item is declared invalid. From the table above, it can be seen that all statement items from each variable pass the validity test. 
Table 4. Reliability Test Results

\begin{tabular}{ccc} 
Variables & $\begin{array}{c}\text { Cronbach's } \\
\text { Alpha }\end{array}$ & Results \\
\hline $\begin{array}{c}\text { Career Development } \\
\left(\mathrm{X}_{1}\right)\end{array}$ &, 873 & Reliable \\
$\begin{array}{c}\text { Work Discipline } \\
\left(\mathrm{X}_{2}\right)\end{array}$ &, 818 & Reliable \\
$\begin{array}{c}\text { Job Satisfaction } \\
(\mathrm{Y})\end{array}$ &, 866 & Reliable \\
\hline Source : Data proccesed by author $(\mathbf{2 0 2 1})$
\end{tabular}

A reliability test is used to determine the consistency of research instruments, in this case, the questionnaire used. From this test, it can be seen whether the instrument will remain consistent. A reliability test is a continuation of the validity test, where items that enter testing are only valid items. Validity test results can be seen from the value of Cronbach's Alpha, where if the value is greater than 0.6 , the variable is declared reliable. From the table below, it can be seen that the value of Cronbach Alpha for each variable is greater than 0.6 , so it can be concluded that the instrument used in this research is reliable.

Table 5. Normality Test Results

\begin{tabular}{ccc} 
Variables & $\begin{array}{c}\text { Asymp. Sig. } \\
(\text { 2-tailed })\end{array}$ & Results \\
\hline $\begin{array}{c}\text { Career Development } \\
\left(\mathrm{X}_{1}\right)\end{array}$ &, 265 & Normal \\
$\begin{array}{c}\text { Work Discipline } \\
\left(\mathrm{X}_{2}\right)\end{array}$ &, 059 & Normal \\
$\begin{array}{c}\text { Job Satisfaction } \\
(\mathrm{Y})\end{array}$ &, 231 & Normal \\
\hline $\begin{array}{c}\text { Source }: \text { Data proccesed by author } \mathbf{( 2 0 2 1 )}\end{array}$
\end{tabular}

The normality test is used to see whether the residual value is generated from regression is distributed normally or not. For this study, normality testing was carried out with the Kolmogorov-Smirnov test. If the value of the test results is $>0.05$, it can be said if the data residual has been normally distributed. From the table below, it can be seen that the significance value of each variable is greater than 0.05 . Thus the research data can be declared normally distributed.

Table 6. Linearity Test Results

\begin{tabular}{ccc} 
Variables & Linearity & Results \\
\hline $\begin{array}{c}\text { Career Development } \\
\left(\mathrm{X}_{1}\right)\end{array}$ &, 000 & Linear \\
$\begin{array}{c}\text { Work Discipline } \\
\left(\mathrm{X}_{2}\right)\end{array}$ &, 000 & Linear \\
\hline \multicolumn{2}{c}{ Source : Data proccesed by author $(\mathbf{2 0 2 1})$}
\end{tabular}


The linearity test is used to know the linearity of the data, which is whether each variable has a linear relationship or not. Two variables are said to have a linear relationship if the significance value of small linearity from 0.05 . If the data studied is not linear, the regression analysis cannot be continued. From the table below, it can be seen that the linearity value of each variable is smaller than 0.05 . Thus the relationship between each independent variable on the bound variable can be declared linear.

Table 7. Multicollinearity Test Results

\begin{tabular}{cc} 
Variables & VIF \\
\hline Career Development & 1,802 \\
$\left(\mathrm{X}_{1}\right)$ & \\
Work Discipline & 1,802 \\
$\left(\mathrm{X}_{2}\right)$ &
\end{tabular}

Source : Data proccesed by author (2021)

The purpose of the multicollinearity test is to test if there is a correlation between the independent variables which are on a regression model of a study. In addition, the multicollinearity test itself can be measured by looking at the value or score of the VIF (variance inflation factor), and if the score of VIF $<5$, the research does not have multicollinearity. From the table below, it can be seen that the VIF value for X1 and X2 variables is smaller than 5 , so it can be concluded that there is no multicollinearity.

Table 8. Heteroscedasticity Test Results

\begin{tabular}{cc} 
Variables & Sig. \\
\hline $\begin{array}{c}\text { Career Development } \\
\left(\mathrm{X}_{1}\right)\end{array}$ &, 538 \\
$\begin{array}{c}\text { Work Discipline } \\
\left(\mathrm{X}_{2}\right)\end{array}$ &, 240 \\
\hline ree : Data proccesed by author $(\mathbf{2 0 2 1})$
\end{tabular}

The heteroscedasticity test is used to test whether in a regression model exists inequality in residual variance from one observation to another observation. In this test, the method used is the Glejser test. If the significance value between the independent variable and absolute residual (abs_res) is more significant than 0.05, there is no heteroscedasticity problem. From the table below, it can be seen that the significance value of each variable on absolute residual is greater than 0.05 , so it can be concluded that there is no heteroscedasticity. 
Table 9. Multiple Linear Regression Results

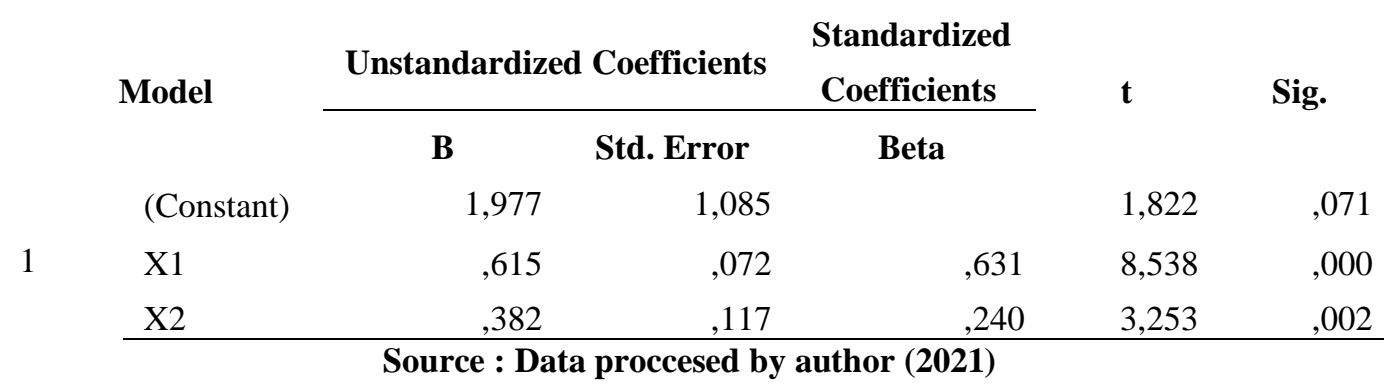

Multiple linear regression analysis is one method that can be used in predicting future situations using past data and can see the influence of two or more independent variables on one dependent variable. Based on the table above, regression equations can be explained with this equation:

$$
\mathrm{Y}=1,977+0,615 \mathrm{X} 1+0,382 \mathrm{X} 2
$$

The intercept value in the equation is 1.977. This value shows that if Career Development and Work Discipline variables are constant, then the deal of Job Satisfaction (Y) is 1.977. Meanwhile, the coefficient value of the Career Development variable (X1) is 0.615. This value indicates that if the Career Development variable increases by one unit, assuming the value of other variables remains constant, the value of Job Satisfaction (Y) will increase by 0.615 . Finally, the coefficient value of the Work Discipline variable (X2) is 0.382. This value shows that if the Work Discipline variable increases by one unit, assuming the value of other variables remains constant, the value of Job Satisfaction (Y) will also increase by 0.382 .

T-test shows how far the independent variables partially affect the dependent variable. In the T-test, if the value of $t$ count is greater than the table, or if the significance value is smaller than 0.05, the Ho hypothesis is rejected, and Ha is accepted. For career development variable (X1) has a t-count value of 8.538, which is greater than the t-table value (1.981567), and has a significance value of 0.000 which is smaller than 0.05 . These values indicate that Career Development has a significant influence on Job Satisfaction of Programming employees of PT. X, so that the hypothesis Ha1 is accepted and Hol is rejected. Meanwhile, the work discipline variable (X2) has a t-count value of 3.253, which is greater than the t-table value (1.981567) and has a significance value of 0.002 , which is smaller than 0.05. These values indicate that Work Discipline has a significant effect 
on Job Satisfaction of Programming employees of PT. X, so that the hypothesis Ha2 is accepted and $\mathrm{Ho} 2$ is rejected.

Table 10. F Test Results

\begin{tabular}{rlrrrrr} 
& Model & $\begin{array}{c}\text { Sum of } \\
\text { Squares }\end{array}$ & df & $\begin{array}{c}\text { Mean } \\
\text { Square }\end{array}$ & \multicolumn{1}{c}{ F } & \multicolumn{1}{c}{ Sig. } \\
\hline \multirow{2}{*}{1} & Regression & 1815,276 & 2 & 907,638 & 108,577 &, $000^{\mathrm{b}}$ \\
& Residual & 944,612 & 113 & 8,359 & & \\
\cline { 2 - 6 } & Total & 2759,888 & 115 & & &
\end{tabular}

The $\mathrm{F}$ test shows how far all the independent variables together affect the dependent variable. The hypothesis will be accepted if the value of the $\mathrm{F}$ count is greater than the $\mathrm{F}$ table or if the significance value is smaller than 0.05. Based on the table above, it can be seen that all independent variables have a significance value of 0.000 which is smaller than 0.05. This shows that Ho3 is rejected and Ha3 is accepted. So it can be concluded that Career Development and Work Discipline together have a significant influence on Job Satisfaction of Programming employees of PT. X.

Table 11. Coefficient Determination Test Results

\begin{tabular}{ccccc} 
Model & R & R Square & $\begin{array}{c}\text { Adjusted R } \\
\text { Square }\end{array}$ & $\begin{array}{c}\text { Std. Error of } \\
\text { the Estimate }\end{array}$ \\
\hline 1 &, $811^{\mathrm{a}}$ &, 658 &, 652 & 2,891 \\
\hline \multicolumn{4}{c}{ Source } & Data proccesed by author (2021)
\end{tabular}

The determination coefficient test determines how much contribution is between all independent variables to the dependent variable. The coefficient of determination can be seen from the Adjusted R-Square value and ranges from 0 to 1. Based on the table above, it can be seen that the Adjusted R-Square value is 0.652. This shows that the variables of Career Development and Work Discipline of Programming employees of PT. X influences Job Satisfaction Programming employees of PT. X is $65.2 \%$, while the rest $(34.8 \%)$ is influenced by other variables.

Based on the study results, it can be concluded that Career Development has a significant positive effect on Job Satisfaction of Programming employees of PT. X. This shows that the better career development felt by employees, the higher the job satisfaction felt by employees. However, if the perceived career development is getting worse, the employee's job satisfaction will decrease.

Several studies explain this effect. Manonmani (2019) states that success in careers achieved by employees will positively impact the employee's personal life because 
employees have the opportunity to meet their needs and improve their standard of living Therefore, with a budding career, employees will feel satisfied with their work. Rahman et al. (2016) also stated the same thing, which explained that good career development would increase the benefits received by employees from their company, ranging from salaries, benefits, and the prestige of their work, so that employees will feel satisfied with their job because of the benefits they receive from their work. Will improve the welfare of the employee.

In addition, Parashakti et al. (2019) explain that employees' career development shows the recognition given by superiors to employee performance. This is because if the employee's work is recognized by others, then the opportunity for employees to develop careers is more open, and employees will feel satisfied with their work. Kaya \& Ceylan (2014) said the same thing, where current employees are looking for financial satisfaction and moral satisfaction. Each employee will have career ambitions that they hope they will derive from their work. Therefore, if employees can develop their careers, employee satisfaction will also increase.

Kitana \& Karam (2017) revealed that career development has a significant positive effect on job satisfaction because career development is evidence of policies that favor employee welfare. Considering that the party that has an active role in career development is the company, the company must carry out programs that aim to make career development policies successful so that indirectly employees feel cared for and appreciated by the company. The same thing was also expressed by Sheraz et al. (2019), where if employees are allowed to develop their careers, it will make employees feel important by their company, and they are happy to enjoy their work. They are given the tools to do their job well, but they can also develop new abilities and achieve a better career.

Based on the study results, it can be concluded that Work Discipline has a significant positive effect on Job Satisfaction of Programming employees of PT. X. This shows that the better the employee's work discipline, the higher the job satisfaction felt by the employees. However, if work discipline worsens, employee job satisfaction will decrease. This effect is explained by several studies. Sudarsih \& Supriyadi (2019) stated that company regulations were formed to direct employees to complete the tasks and work 
assigned to them properly following the standards set by the company. So that when they can behave in a disciplined manner, their work can be completed properly so that employees can feel satisfied with the results of their work. The same thing was expressed by Yadewani \& Wijaya (2019), where work discipline is very much needed by employees and companies. This is because discipline towards regulations has an important role in achieving company goals, as well as employee career goals. If these two things are completed, it will appear satisfaction in employees.

Another opinion from Harinoto (2017) explains that self-discipline from employees can train, improve, and shape the knowledge, attitudes, and behavior of the employees themselves so that when employees carry out their work, they can do their jobs optimally so that employees will feel more satisfied than before. Then Ifriana \& Susanti (2019) stated, the existence of work discipline will increase employee enthusiasm and high work enthusiasm and will encourage employees to work more productively so that in turn will be able to increase employee work productivity. Those who have high spirits, obey the rules set by the institution, are creative, and can use the facilities properly will be able to compete in the current increasingly competitive conditions.

Yuliandi \& Tahir (2019) explained that good employee discipline reflects the magnitude of a person's responsibility for the tasks assigned to him. This encourages work morale, work enthusiasm, and the realization of the goals of the company and its employees, which in turn will create job satisfaction for employees. This is explained by Jayanti et al. (2020), where work discipline is included in employee psychological factors. Psychological factors are factors related to the psychological condition of employees, which include interest, calmness at work, attitudes towards work, talents, and skills. Given that work discipline is a form of employee attitude towards work, good work discipline will indicate good employee psychological factors, and in the end, will create good job satisfaction.

\section{CONCLUSION}

Based on the research results discussed, several conclusions can be drawn-description of Career Development perceived by Programming employees of PT. X is very low. This 
can be seen from the career planning factor that employees feel is very low because many employees do not have work experience that can help them develop their careers. In addition, career development, when viewed from the career management factor, is also very low due to many employees who consider that the company does not have a rotation program that can help employees find work passion. Finally, when viewed from the Career Information factor, career development is also very low, which is because many employees feel that the company does not openly disseminate information related to career development.

Also, description of Work Discipline of Programming employees of PT. X is very low. This can be seen from the very low regulatory factor, which is because almost all employees consider that the regulations that apply in the company are still unclear and have multiple interpretations. Then, work discipline, when viewed from the action factor, is also very low, which is because many employees feel that the preventive policies implemented by the company are still not good in improving discipline in the company. Then, description of Job Satisfaction felt by Programming employees of PT. X is classified as low. This can be seen from the factor of working conditions that employees feel is still low, which is because many employees feel that security and comfort at work have not supported them in doing their jobs. In addition, the compensation factor is also relatively low, which is because many employees feel they do not get incentives from their companies. Finally, the leadership factor handled by employees is still low because many employees feel they are not being treated fairly by their superiors.

For the research results, career development has a significant positive effect on the Job Satisfaction of Programming employees of PT. X. This shows that the better career development felt by employees, the higher the job satisfaction felt by employees. However, if the perceived career development is getting worse, the employee's job satisfaction will decrease. Meanwhile, work discipline has a significant positive effect on Job Satisfaction of Programming employees of PT. X. This shows that the better the employee's work discipline, the higher the job satisfaction felt by the employees. However, if work discipline worsens, employee job satisfaction will decrease. Lastly, the career development and work discipline model can predict employees' job satisfaction in the programming department at PT. X. 
This research also has several implications for the company's management. Many respondents respond positively to the "Companies has carry out training programs that help develop careers" statement in career development. This implies that employees feel that the training programs implemented by the company have made it easier for employees to develop their careers. In work discipline, many respondents respond positively to the statement of "The company issues regulations are reasonable enough to be obeyed" and "There are no overlapping regulations within the company." This has implications where employees feel that the rules applied in the company are reasonable to obey and there are no overlapping regulations in the company. In job satisfaction, many respondents respond positively to the "The company provides a salary that is sufficient for my daily needs" statement. This implies that employees feel that the salary they receive from the company is sufficient for fulfilling their daily needs.

For academic implications, the research's results regarding career development are in line with the results from Santoso \& Sidik (2020), Manonmani (2019), Sheraz et al. (2019), Kitana \& Karam (2017), and Rahman et al. (2016) who stated that career development has a significant positive effect on job satisfaction. The research's results regarding work discipline are in line with the results from Santoso \& Sidik (2020), Yadewani \& Wijaya (2019), Sudarsih \& Supriyadi (2019), Ifriana \& Susanti (2019), and Yuliandi \& Tahir (2019), who stated that work discipline has a significant positive effect on job satisfaction. Based on these conclusions, the researcher provides several recommendations that can be applied by the company. On career development issues, researchers advise companies to offer more varied tasks to employees, as well as provide job rotations that are in accordance with employee capabilities so that employees can have wider work experience that helps employees in developing their careers. Then the company can implement a rotation policy that is not only good but also transparent so that it can help employees find their work passion. Finally, the company uses several mediums aimed at disseminating information related to career development openly so that information related to employee career development can be conveyed to all employees without exception. Meanwhile, on the issue of work discipline, the researcher gives advice to the company to clarify and detail the regulations that apply within the company by changing or amending these regulations, taking into account suggestions from employees as one of 
the important elements of the company. In addition, the company can improve preventive policies within the company, which can prevent employees from being undisciplined, by involving employees as parties who are directly affected by the policy so that the policies that will be formed can meet the interests of both parties..

\section{REFERENCES}

Aluf, W. al, Sudarsih, Musmedi, D. P., \& Supriyadi. (2017). Assessing the Impact of Motivation, Job Satisfaction, and Work Environment on The Employee Performance in Healthcare Services. International Journal of Scientific \& Technology Research, 6(10), 337-341.

Arab, A. M., Nurmayanti, S., \& Furqan, L. (2019). Effect of Locus of Control, NonPhysical Work Environment and Work Discipline on Job Satisfaction. International Journal of Humanities, Religion and Social Science, 3(2), 17-37.

Bugdol, M. (2018). A Different Approach to Work Discipline. Palgrave Macmillan.

Fadhilah, M. L. (2010). Analisis Pengaruh Stress Kerja terhadap Kepuasan Kerja dengan Dukungan Sosial sebagai Variabel Moderating (Studi Pada PT. Coca Cola Amatil Indonesia, Central Java). Universitas Diponegoro.

Harinoto. (2017). The Role of Organizational Culture and Work Discipline on Job Performance Mediated Job Satisfaction. Management and Business Review, 1(1), $17-23$.

Ifriana, \& Susanti, F. (2019). Pengaruh Lingkungan Kerja dan Disiplin Kerja terhadap Kepuasan Kerja Karyawan pada Kantor Samsat Painan.

Ilahi, D. K., Mukzam, M. D., \& Prasetya, A. (2017). Pengaruh Kepuasan Kerja terhadap Disiplin Kerja dan Komitmen Organisasional (Studi pada Karyawan PT. PLN (Persero) Distribusi Jawa Timur Area Malang). Jurnal Administrasi Bisnis, 44(1), 31-39.

Jayanti, E., Utaminingtyas, R. R. B., \& Farouk, U. (2020). The Effect of Work Motivation , Work Discipline, and Work Environment on Employee Job Satisfaction at PT . Samudera Perdana Selaras. Admisi Dan Bisnis, 21, 131-142. https://journal.polines.ac.id/index.php/admisi 
Jena, L., \& Nayak, U. (2020). Theories of Career Development: An Analysis. Indian Journal of Natural Sciences, 10(60), 23515-23523.

Kaya, Ç., \& Ceylan, B. (2014). An Empirical Study on the Role of Career Development Programs in Organizations and Organizational Commitment on Job Satisfaction of. American Journal of Business and Management, 3(3), 178-191. https://doi.org/10.11634/216796061403551

Kitana, A., \& Karam, A. A. (2017). The Relationship between Work Environment into Women's Career Development and Job Satisfaction in the United Arab Emirates: A Large Scale Sampling. International Journal of Business and Management Invention, $6(1), 22-28$.

Lusigita, K. (2017). Pengaruh Kepemimpinan dan Disiplin Kerja terhadap Kepuasan Kerja dan Kinerja Pegawai Negeri Sipil pada Dinas Sosial dan Tenaga Kerja Kabupaten Badung. JAGADITHA: Jurnal Ekonomi \& Bisnis, 4(1), 27-37.

Manonmani, A. (2019). A Study of Career Planning and Career Development on Employee Satisfaction in Private Sector Banks at Thanjavur District. Journal of the Gujarat Society, 21(16), 424-437.

Mrhálek, T., \& Kajanová, A. (2017). Work Satisfaction and Mental Pressure of Social Workers and Workers in Social Services. Kontakt, 1-5. https://doi.org/10.1016/j.kontakt.2017.10.001

Natsir, M., Riduwan, A., \& Ujianto. (2018). Employee Satisfaction and Performance?: The Impact Analysis on Leadership, Work Motivation, Work Discipline and Compensation. Journal of Business and Management, 20(4), 6-12.

Parashakti, R. D., Juniarti, S., \& Khotimah, N. (2019). The Effect of Workload, Work Environment, Career Development on Employee Job Satisfaction on PT. Sari Coffee Indonesia, Tbk. Dinasti International Journal of Education Management and Social Science, 1(1), 44-54. https://doi.org/10.31933/DIJEMSS

Parimita, W., Pambudi, W. S., \& Aminah, H. (2017). The Impact of career development and workload toward employee job satisfaction at PT. Askrindo Jakarta. Jurnal Riset Manajemen Sains Indonesia, 8(1), 39-57.

Rahman, H., Rahman, W., Khan, M. A., \& Anwar, K. J. (2016). The Mediating Role of Career Development in its Antecedents and Outcomes: Empirical Evidence from 
Pakistan. Sarhad Journal of Management Sciences, 2(2).

Santoso, J. B., \& Sidik, Y. (2020). Effect of Career Development, Work Discipline and Work Environment to Job Satisfaction. Advances in Economics, Business and Management Research.

Sekaran, U., \& Bougie, R. (2010). Research Methods for Business: A Skill Building Approach. John Wiley \& Sons.

Sheraz, F., Batool, S., \& Adnan, S. (2019). Employee's Retention and Job Satisfaction: Mediating Role of Career Development Programs. The Dialogue, 14(2), 67-78.

Sholikhah, Simanjuntak, A. S., \& Parimita, W. (2018). Pengaruh Pengembangan Karir, Motivasi dan Budaya Organisasi terhadap Kepuasan Kerja pada Karyawan Perum Perumnas Kantor Pusat Jakarta Timur. Jurnal Riset Manajemen Sains Indonesia, 9(2), 299-319.

Singh, T., Chetty, N., \& Karodia, A. M. (2016). An Investigation into the Impact of Absenteeism on the Organisational Performance of a Private Security Company in Durban, Kwazulu-Natal. Singaporean Journal of Business Economics, and Management Studies, 4(11), 105-159.

Sudarsih, \& Supriyadi. (2019). The Role of Workload and Work Discipline in Improving Job Satisfaction. International Journal of Scientific Research and Management, 7(10), 1375-1383. https://doi.org/10.18535/ijsrm/v7i10.em03

Tepret, N. Y., \& Tuna, K. (2015). Effect of Management Factor on Employee Job Satisfaction: an Application in Telecommunication Sector. Procedia - Social and Behavioral Sciences, 195(224), 673-679. https://doi.org/10.1016/j.sbspro.2015.06.264

Yadewani, D., \& Wijaya, R. (2019). The Relationship between Reward, Work Discipline, Motivation and Employee Job Satisfaction among Employees of Inews TV Padang, Indonesia. International Journal of Recent Technology and Engineering, 8(2), 491494.

Yuliandi, \& Tahir, R. (2019). Work discipline, competence, empowerment, job satisfaction, and employee performance. International Journal of Recent Technology and Engineering, 8(3), 7209-7215. https://doi.org/10.35940/ijrte.C6221.098319 
Zainal, H. (2017). Influence of Work Motivation and Discipline on Work Productivity. Advances in Social Science, Education and Humanities (ASSEHR), 149, 25-27. 